\title{
Quality of adzuki bean seeds desiccated with flumioxazin and subjected to storage*
}

\section{Qualidade de sementes de feijão azuki dessecadas com flumioxazin e submetidas ao armazenamento}

\author{
Cássio Jardim Tavares ${ }^{1}$ (1) (https://orcid.org/0000-0003-2813-8442) \\ Morgana Soares Sousa ${ }^{2}$ (1) (https://orcid.org/0000-0002-9764-988X) \\ Marco Antonio Moreira de Freitas ${ }^{3}$ (1) (https://orcid.org/0000-0001-6718-4906) \\ Juliana de Fátima Sales ${ }^{2}$ (1) (https://orcid.org/0000-0002-6113-2707) \\ Osvaldo Resende 2 (1) (https://orcid.org/0000-0001-5089-7846) \\ Adriano Jakelaitis $2 * *$ (1) (https://orcid.org/0000-0003-0093-9846)
}

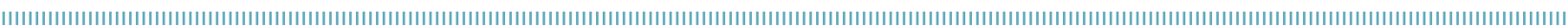

\begin{abstract}
Production and storage environments influence the physiological and sanitary quality of seeds. This study aimed to evaluate the effects of the herbicide flumioxazin applied as a preharvest desiccant and storage on the physiological and sanitary quality of adzuki bean seeds. A randomized block design was used in a split-plot scheme, with four replications. Plots consisted of five doses of the herbicide

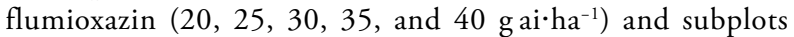
consisted of two evaluation times (harvest and six months after harvest). Two controls, with no herbicide application, were tested for each evaluation time. The physiological seed quality was maintained with doses from 25 to $35 \mathrm{~g} \cdot \mathrm{ha}^{-1}$ of flumioxazin. Increasing herbicide doses reduced the electrical conductivity of seeds. The increased doses also reduced the percentage of normal seedlings in the first germination count after six months of storage and caused seedling vigor loss. The storage of adzuki bean for six months reduced its physiological quality, leading to losses in germination and seed vigor. Storage and increasing doses of the desiccant flumioxazin reduced the incidence of the pathogens Rhizopus, Cladosporium, and Fusarium in the seeds. The increased doses of this herbicide reduced Aspergillus incidence. Penicillium incidence was not affected by treatments.
\end{abstract}

KEYWORDS: desiccant; herbicide; pathogens; Vigna angularis.
RESUMO: A qualidade fisiológica e sanitária de sementes é influenciada pelo ambiente de produção e de armazenamento. Neste trabalho objetivou-se avaliar os efeitos do herbicida flumioxazin aplicado como dessecante em pré-colheita e do armazenamento sobre a qualidade fisiológica e sanitária de sementes de feijáo azuki. Foi adotado o delineamento experimental em blocos ao acaso, em esquema de parcelas subdivididas. Nas parcelas foram alocadas as cinco doses do herbicida flumioxazin $\left(20,25,30,35\right.$ e 40 g i.a.ha $\left.{ }^{-1}\right)$ e nas subparcelas as duas épocas de avaliaçáo (colheita e 6 meses após a colheita), com quatro repetiçóes. Foram testados dois tratamentos sem aplicação do herbicida para cada época de avaliação. Nas doses entre 25 a $35 \mathrm{~g} \cdot \mathrm{ha}^{-1}$ de flumioxazin observou-se a manutenção da qualidade fisiológica das sementes. Em doses crescentes reduziu-se a condutividade elétrica das sementes. $\mathrm{O}$ aumento das doses reduziu a porcentagem de plântulas normais na primeira contagem da germinação, após seis meses de armazenamento, e causou perda no vigor das plântulas. $\mathrm{O}$ armazenamento de feijão azuki durante seis meses reduziu a qualidade fisiológica, causando perdas na germinação e vigor das sementes. $\mathrm{O}$ armazenamento e o aumento das doses do dessecante flumioxazin reduziram a incidência dos patógenos Rhizopus, Cladosporium e Fusarium nas sementes. O aumento das doses reduziu a incidência de Aspergillus. A incidência de Penicillium não foi afetada pelos tratamentos.

PALAVRAS-CHAVE: dessecante; herbicida; patógenos; Vigna angularis.

\footnotetext{
'Instituto Federal de Educação Ciência e Tecnologia Goiano - Diretoria de Pesquisa, Pós-Graduação e Inovação - Cristalina (GO), Brazil. ${ }^{2}$ Instituto Federal de Educação Ciência e Tecnologia Goiano - Diretoria de Pós-graduação, Pesquisa e Inovação, Programa de Pós-Graduação em Ciências Agrárias, Rio Verde (GO), Brazil.

${ }^{3}$ Instituto Federal de Educação Ciência e Tecnologia Goiano - Diretoria de Pesquisa e Pós-Graduação, Programa de Pós-Graduação em Proteção de Plantas Urutaí (GO), Brazil.

*This article is part of the master's thesis of the first author.

**Corresponding author: adriano.jakelaitis@ifgoiano.edu.br

Received on: 07/23/2018. Accepted on: 07/13/2020
} 


\section{INTRODUCTION}

Adzuki bean (Vigna angularis L.) is produced and consumed mainly in China, Japan, and Korea. In Brazil, it is consumed mainly as sweets and countless oriental delicacies, being also prepared similarly to common beans (Phaseolus vulgaris L.) and found in medium or large grocery stores, but with a much higher price (ALMEIDA et al., 2013). There are no exact statistics in Brazil regarding production or area cultivated with adzuki beans. However, research on this crop has been growing in Brazil involving mainly genotypes (CARVALHO et al., 2012), cultivation practices (GUARESCHI et al., 2013; BASTOS et al., 2013), and postharvest techniques (RESENDE et al., 2012; OLIVEIRA et al., 2014).

The chemical desiccation technique has been used more and more in a large number of crops in an attempt to find the right time and a possible early harvest, without production losses (FRANCO et al., 2013). Desiccation has been carried out aiming to control weeds and cause crop defoliation, providing an early harvest and facilitating the work of combine harvesters in the field (DALTRO et al., 2010). However, factors such as the choice of the herbicide, application time, and the appropriate dose for the application must be taken into account to avoid reducing production and seed quality (TOLEDO et al., 2012).

The herbicide flumioxazin is recommended for preemergence, incorporated preplanting, or postemergence applications in various crops and has a desiccant action for promoting early harvest and uniform maturation (SOLTANI et al., 2013; ATAIDE et al., 2015). It has contact action and acts by inhibiting the enzyme protoporphyrinogen oxidase (PROTOX). Its activity is expressed by leaf necrosis, produced by the peroxidation of cell membrane lipids, induced by the formation of singlet oxygen in the presence of light and oxygen (TIBURCIO et al., 2012).

Another important factor for seed quality is storage. SMANIOTTO et al. (2014) reported that storage is necessary to meet the logistics of production and commercialization of agricultural products. A reduction in seed quality is usually related to a decrease in the percentage of germination, an increase in abnormal seedlings, and a decrease in seedling vigor (TOLEDO et al., 2012). FORTI et al. (2010) observed, through germination and vigor tests, that the storage environment influences the quality of soybean seeds.

Given the importance of desiccation to anticipate and standardize the harvest process and the effect of storage on maintaining seed vigor, this research aimed to verify the effects of doses of the herbicide flumioxazin applied as a preharvest desiccant and storage on the physiological and sanitary quality of adzuki bean seeds.

\section{MATERIAL AND METHODS}

This research was conducted at the Federal Institute of Goiás, campus of Rio Verde, GO, Brazil, under the geographic coordinates $17^{\circ} 48^{\prime} 67^{\prime \prime} \mathrm{S}$ and $50^{\circ} 54^{\prime} 18^{\prime \prime} \mathrm{W}$ and an altitude of $754 \mathrm{~m}$. The experimental area was installed on an oxisol and presented the following physicochemical characteristics, determined at a depth of $0-20 \mathrm{~cm}: \mathrm{pH}\left(\mathrm{CaCl}_{2}\right)$ of 5.2, $\mathrm{P}$ of $11 \mathrm{mg} \cdot \mathrm{dm}^{-3}$, K of $246 \mathrm{mg} \cdot \mathrm{dm}^{-3}$, Ca of $5.77 \mathrm{cmol}_{\mathrm{c}} \cdot \mathrm{dm}^{-3}, \mathrm{Mg}$ of $1.63 \mathrm{cmol}_{\mathrm{c}} \cdot \mathrm{dm}^{-3}$, $\mathrm{Al}$ of $0.03 \mathrm{cmol}_{\mathrm{c}} \cdot \mathrm{dm}^{-3}$, base saturation of $64.6 \%$, and particle size distribution of 46,10 , and $44 \mathrm{dag} \cdot \mathrm{kg}^{-1}$ of clay, silt, and sand, respectively. The regional climate is Aw (Köppen-Geiger), i.e., tropical with precipitations concentrated in the summer (October to April) and a well-defined dry period during the winter season (May to September), with mean annual precipitation varying from 1200 to $1500 \mathrm{~mm}$.

A randomized block design was used in a split-plot scheme, with four replications. Plots consisted of five doses of the herbicide flumioxazin $\left(20,25,30,35\right.$, and $40 \mathrm{~g}$ ai $\left.\cdot \mathrm{ha}^{-1}\right)$, while subplots consisted of two evaluation times of the physiological and sanitary seed quality (harvest and six months after harvest). Two controls were used as additional treatments for each evaluation time, consisting of seeds not treated with the desiccant. Each experimental unit had $20 \mathrm{~m}^{2}$, consisting of eight planting rows $5 \mathrm{~m}$ long, with a useful area composed of the four central rows, not considering the borders and $0.5 \mathrm{~m}$ of each end.

Soil tillage was carried out utilizing one plowing and two harrowing operations and the semimechanized sowing of the adzuki bean was conducted on November 28, 2013, with a density of 18 seeds per linear meter. Sowing was carried out at a depth of $4 \mathrm{~cm}$, and the base fertilization was performed in the sowing furrow using $350 \mathrm{~kg} \cdot \mathrm{ha}^{-1}$ of the formulation 02-20-18 $\left(\mathrm{N}-\mathrm{P}_{2} \mathrm{O}_{5}-\mathrm{K}_{2} \mathrm{O}\right)$. The topdressing fertilization was conducted after 25 days using $60 \mathrm{~kg} \cdot \mathrm{ha}^{-1}$ of $\mathrm{N}$ applied as urea.

Weed control was carried out by manual weeding until the crop canopy closure when the adzuki bean began to suppress weed development due to shading. Phytosanitary treatments were performed at 28 and 42 days after sowing by applying the fungicide pyraclostrobin at the dose of $0.075 \mathrm{~kg} \cdot \mathrm{ha}^{-1}$ and the insecticide thiamethoxam at the dose of $0.060 \mathrm{~kg} \cdot \mathrm{ha}^{-1}$.

The desiccant herbicide was applied at 68 days after sowing (DAS) when plants had a pod with a typically mature color. The herbicide was applied using a $\mathrm{CO}_{2}$-pressurized knapsack sprayer with four spray tips model TT11003, at a constant pressure of $2.5 \mathrm{bar}$ and spray volume of 250 liters.ha ${ }^{-1}$.

The adzuki bean was harvested manually when it had $12 \%$ water content, determined by the oven method. The seeds were packed in paper bags and stored under ambient conditions in the laboratory of postharvest for six months. The relative humidity $(\mathrm{RH})$ and the temperature inside the laboratory were recorded by a digital data logger (precision: $0.1{ }^{\circ} \mathrm{C}$ and $5.0 \% \mathrm{RH}$ ), reaching mean temperature and $\mathrm{RH}$ values of $25.4 \pm 3{ }^{\circ} \mathrm{C}$ and $67.3 \pm 3 \%$ during the experimental period.

The physiological quality of seeds was evaluated through water content, germination, accelerated aging, electrical 
conductivity, emergence and emergence rate index, and sanity tests, as follows:

a) Water content: determined according to the rules for seed testing (RAS) by the oven method at $105 \pm 3{ }^{\circ} \mathrm{C}$ for $24 \mathrm{~h}$ (BRASIL, 2009), with four subsamples of 50 seeds. The result was expressed as the percentage of wet basis (\% wb).

b) Germination test: performed with four subsamples of 50 seeds per treatment, which are packed in rolls of germitest paper moistened with distilled water in a volume equivalent to 2.5 times the mass of the dry substrate. These rolls were placed in a germinator regulated at a constant temperature of $30{ }^{\circ} \mathrm{C}$ during daytime and $20{ }^{\circ} \mathrm{C}$ during nighttime. Counts were performed on the fourth and ninth days after the test was installed, with results expressed as the percentage of normal seedlings (BRASIL, 2009).

c) Emergence test and emergence rate index: conducted in a greenhouse, with four replications of 50 seeds and sowing in the sand at a $3 \mathrm{~cm}$ depth. The substrate was moistened to $70 \%$ of its field capacity at sowing time, being sprinkling irrigated three times a day. Daily counts of seedling emergence above $1 \mathrm{~cm}$ were performed to determine the seedling emergence rate index (ERI), according to MAGUIRE (1962). Seedling length and dry matter were evaluated using normal seedlings from the emergence test at 10 days after sowing. Hypocotyl and epicotyl length were measured 20 seedlings using a ruler. The dry matter was determined by packing the seedlings in paper bags and submitting them to dry in an air circulation oven at a temperature of $65^{\circ} \mathrm{C}$ for $48 \mathrm{~h}$. After drying, these samples were weighed on an electronic scale with a $0.001-\mathrm{g}$ precision.

d) Electrical conductivity test: performed using four replications of 50 seeds from each treatment, which were previously weighed on a $0.01-\mathrm{g}$ precision scale and placed in plastic cups with $75 \mathrm{~mL}$ of distilled, deionized water, remaining under soaking in a BOD incubator at a constant temperature of $25^{\circ} \mathrm{C}$. The electrical conductivity of the solutions was read after $24 \mathrm{~h}$ using a Technal TEC-4MP digital conductivity meter. The results were expressed in $\mu S \cdot \mathrm{cm}^{-1} \cdot \mathrm{g}^{-1}$ of seed (VIEIRA; KRZYZANOWSKI, 1999).

e) Accelerated aging: four replicates of 50 seeds were used in the accelerated aging test. The test was conducted in gerboxes with an aluminum screen inside, with the seeds distributed in a uniform layer. A total of $40 \mathrm{~mL}$ of distilled water was added to each box, and the 50 seeds were placed on the screen. These boxes were covered and placed in a germination chamber regulated at a temperature of $41{ }^{\circ} \mathrm{C}$ for $24 \mathrm{~h}$. After aging, the seeds were subjected to the germination test, as previously described, with results expressed as the percentage of normal seedlings.

f) Sanity test: the blotter test method was used, as described by NEERGAARD (1979). Four replications of 100 seeds were placed on three sheets of filter paper previously sterilized under a dry condition and moistened with distilled and autoclaved water at $1 \%$ sodium chloride, being then placed in gerbox-type plastic boxes, with 25 seeds per box. Pathogens were identified after seven days of incubation at $20 \pm 2{ }^{\circ} \mathrm{C}$ and $12 \mathrm{~h}$ of light. At the end of this period, the seeds were examined individually using a stereomicroscope with a magnification of up to $60 \times$. Microscopic preparations were prepared when necessary to identify the fungi.

The results were subjected to analysis of variance by the F-test. Regression analysis as a function of the desiccant doses was applied when the results were significant. The F-test was used for means referring to the evaluation times and the Dunnett's test was used for contrasts between the means and the comparative control without desiccant application. The comparative control for the Dunnett's test was the control without flumioxazin used in the harvest. The statistical significance level for all tests was 5\%.

\section{RESULTS AND DISCUSSION}

The water content, germination, emergence, emergence rate index, electrical conductivity, and accelerated aging tests showed effects of the main factors regarding flumioxazin doses for root length and total seedling length (Fig. 1); evaluation time for abnormal seedlings, percentage of normal seedlings in germination, germination after accelerated aging test, root and hypocotyl length and dry matter, and total seedlings (Table 1); and interaction for electrical conductivity, emergence rate index, and normal seedlings at the first count (Table 2). Seed water content and percentage of emergence were not influenced by the sources of variation (Table 1).

Seed water content showed mean values of $12.42 \%$ (wb) (Table 1). These values are similar to those found when the

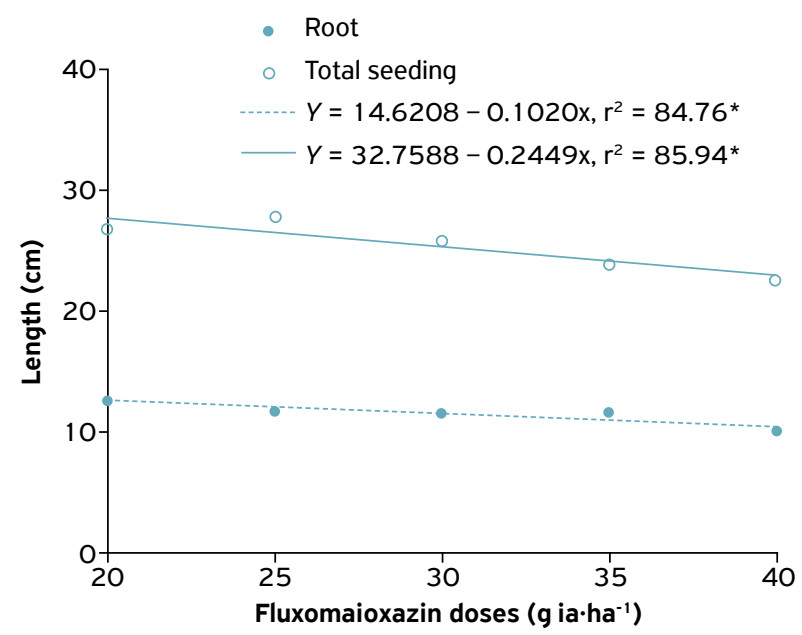

*Significant at $\mathrm{p} \leq 0.05$ by $\mathrm{F}$ test.

Figure 1. Root length and total length of seedlings from adzuki bean seeds treated with doses of the desiccant flumioxazin. 
Table 1. Water content (WC), hypocotyl length (HL), root length (RL), total length of seedlings (TL), hypocotyl dry matter (HDM), root dry matter (RDM), total dry matter (TDM), normal seedlings after accelerated aging (NSAA), abnormal seedlings (AS), and normal seedlings at germination (NS) and emergence (E) of adzuki bean seeds according to the dose of the desiccant flumioxazin applied in the pre-harvest and six months after storage (6 MAS).

\begin{tabular}{|c|c|c|c|c|c|c|c|c|c|c|c|}
\hline \multirow{2}{*}{ Treatment } & $W^{1}$ & HL & $\mathbf{R L}$ & TL & HDM & RDM & TDM & NSAA & AS & NS & E \\
\hline & $\%$ wb & \multicolumn{3}{|c|}{$\mathrm{cm}$} & \multicolumn{3}{|c|}{ g } & \multicolumn{4}{|c|}{$\%$} \\
\hline $20\left(\right.$ g ai $\left.\cdot h a^{-1}\right)$ & 12.41 & 11.24 & 12.65 & 26.89 & 0.39 & 0.33 & 0.73 & 59.75 & 9.75 & 87.75 & 88.25 \\
\hline $25\left(\right.$ g ai ha $\left.^{-1}\right)$ & 12.59 & 11.98 & 11.78 & 27.76 & 0.49 & 0.23 & 0.72 & 56.00 & 8.75 & 89.75 & 88.00 \\
\hline $30\left(\right.$ g ai $\left.\mathrm{ha}^{-1}\right)$ & 12.48 & 12.51 & 12.59 & 25.75 & 0.50 & 0.22 & 0.71 & 67.00 & 13.00 & 84.50 & 91.25 \\
\hline $35\left(\right.$ g ai $\left.h a^{-1}\right)$ & 11.93 & 12.25 & 11.78 & 24.02 & 0.41 & 0.29 & 0.70 & 63.25 & 9.00 & 87.25 & 88.50 \\
\hline $40\left(\mathrm{~g}\right.$ ai $\left.h^{-1}\right)$ & 12.29 & 12.43 & 10.21 - & 22.64- & 0.46 & 0.22 & 0.67 & 62.25 & 10.50 & 86.00 & 94.00 \\
\hline Harvest & 12.27 & $13.43 a$ & $13.62 a$ & $27.06 a$ & $0.74 a$ & $0.40 a$ & $1.14 a$ & $69.00 a$ & $5.70 b$ & $90.80 a$ & 91.90 \\
\hline 6 MAS & 12.41 & $10.73 b-$ & $10.53 b-$ & $21.34 b-$ & $0.16 b-$ & $0.11 b-$ & $0.27 b-$ & 54.30b- & $14.70 a+$ & 83.30b- & 88.10 \\
\hline CWF-Harvest & 13.00 & 13.47 & 15.91 & 29.37 & 0.65 & 0.48 & 1.13 & 70.50 & 2.50 & 93.50 & 88.00 \\
\hline CWF-6 MAS & 12.74 & $11.18-$ & 10.96- & $22.14-$ & $0.13-$ & $0.17-$ & $0.25-$ & 47.00- & $16.00+$ & 83.50- & 89.50 \\
\hline CV A (\%) & 5.45 & 4.59 & 8.32 & 4.79 & 18.47 & 15.47 & 21.08 & 13.28 & 14.80 & 6.60 & 10.77 \\
\hline CV B (\%) & 7.90 & 3.61 & 12.43 & 6.68 & 16.52 & 14.30 & 18.58 & 15.99 & 15.91 & 6.46 & 7.31 \\
\hline
\end{tabular}

'Means followed by the same letter in the columns are statistically equal by the F-test at $5 \%$ significance. Means followed by - or+ are statistically lower or higher than CWF-harvest, respectively, by the Dunnett's test at 5\% significance. CWF - control without flumioxazin application. CV A and CV B are the coefficients of variation of the plot and subplot, respectively.

Table 2. Physiological and sanitary quality of adzuki bean seeds according to the doses of the desiccant flumioxazin applied in the preharvest and six months after storage (6 MAS).

\begin{tabular}{|c|c|c|c|c|c|c|c|}
\hline \multirow{2}{*}{ Treatment } & \multirow{2}{*}{ CWF $^{1}$} & \multicolumn{5}{|c|}{ Flumioxazin doses $\left(\mathrm{g}\right.$ ai $\left.\cdot \mathrm{ha}^{-1}\right)$} & \multirow{2}{*}{ Regression } \\
\hline & & 20 & 25 & 30 & 35 & 40 & \\
\hline \multicolumn{8}{|c|}{ Electrical conductivity $\left(\mu \mathrm{S} \cdot \mathrm{cm}^{-1} \cdot \mathrm{g}^{-1}\right)$} \\
\hline Harvest & 56.75 & $50.92 b$ & $46.49 b-$ & $44.34 b-$ & $43.12 b-$ & $42.67 b-$ & $\hat{Y}=57,4457-0.3980 x, r^{2}=87.08^{* *}$ \\
\hline 6 MAS & $95.86+$ & $89.36 a+$ & $87.19 a+$ & $96.20 a+$ & $95.92 a+$ & $96.16 a+$ & $\hat{Y}=\bar{Y}=92,97$ \\
\hline \multicolumn{8}{|c|}{ Normal seedlingsat first count (\%) } \\
\hline Harvest & 73.50 & $75.5 a$ & $76.5 a$ & $68.50 a$ & $74.60 a$ & $78.5 a$ & $\hat{Y}=\bar{Y}=74.97$ \\
\hline 6 MAS & 68.00 & $66.5 b$ & $63.5 b-$ & 61.00a- & $59.50 b-$ & $60.5 b-$ & $\hat{Y}=71.80-0.32 x, r^{2}=80.50^{*}$ \\
\hline \multicolumn{8}{|c|}{ Emergence rate index } \\
\hline Harvest & 10.08 & $9.84 a$ & $10.28 a$ & $10.02 a$ & $10.51 \mathrm{a}$ & $10.91 \mathrm{a}$ & $\hat{Y}=\bar{Y}=10.31$ \\
\hline 6 MAS & $7.87-$ & $8.66 b-$ & $8.89 b-$ & $8.30 b-$ & $8.09 b-$ & $7.89 b-$ & $\hat{Y}=9.7728-0.0469 x, r^{2}=81.56^{*}$ \\
\hline \multicolumn{8}{|c|}{ Rhizopus incidence (\%) } \\
\hline Harvest & 1.12 & $1.52 \mathrm{a}$ & $1.45 a$ & $1.27 a$ & $1.11 \mathrm{a}$ & $1.07 a$ & $\hat{Y}=2.024-0.0246 x, r^{2}=96.20 * * *$ \\
\hline 6 MAS & $0.58-$ & $0.75 b-$ & $0.72 b-$ & $0.38 b-$ & $0.27 b-$ & $0.25 b-$ & $\hat{Y}=1.3490-0.0291 x, r^{2}=88.92^{*}$ \\
\hline \multicolumn{8}{|c|}{ Fusarium incidence (\%) } \\
\hline Harvest & 7.70 & $6.82 a-$ & $6.32 \mathrm{a}-$ & $5.62 a-$ & $5.10 a-$ & $4.27 a-$ & $\hat{Y}=9.4252-0.1265 x, r^{2}=99.32^{* *}$ \\
\hline 6 MAS & 4.10- & $4.37 b-$ & $4.47 b-$ & $4.62 b-$ & $4.45 a-$ & 4.77a- & $\hat{Y}=\bar{Y}=4.54$ \\
\hline \multicolumn{8}{|c|}{ Cladosporium incidence (\%) } \\
\hline Harvest & 7.92 & $6.42 \mathrm{a}-$ & $6.27 a-$ & $6.12 \mathrm{a}-$ & $5.97 a-$ & $4.72 \mathrm{a}-$ & $\hat{Y}=8.1180-0.0738 x, r^{2}=73.69$ \\
\hline 6 MAS & $4.42-$ & $4.07 b-$ & $3.90 b-$ & $4.45 b-$ & $4.00 b-$ & $3.77 a-$ & $\hat{Y}=\bar{Y}=4.04$ \\
\hline \multicolumn{8}{|c|}{ Penicillium incidence (\%) } \\
\hline Harvest & 2.17 & 2.07 & 2.15 & 2.02 & 1.95 & 2.09 & $\hat{Y}=\bar{Y}=2.05$ \\
\hline 6 MAS & 2.32 & 2.27 & 2.30 & 2.26 & 2.31 & 2.29 & $\hat{Y}=\bar{Y}=2.29$ \\
\hline \multicolumn{8}{|c|}{ Aspergillus incidence (\%) } \\
\hline Harvest & 2.43 & 2.48 & 3.13 & 2.73 & $1.53-$ & $0.60-$ & \multirow{2}{*}{$\hat{Y}=4.1675-0.0705 x, r^{2}=81.13^{*}$} \\
\hline 6 MAS & 2.18 & 2.28 & 2.15 & 2.00 & $1.50-$ & $1.95-$ & \\
\hline
\end{tabular}

${ }^{1}$ Means followed by the same letter in the columns are statistically equal by the F-test at $5 \%$ significance. Means followed by - or + are statistically lower or higher than CWF-Harvest, respectively, by the Dunnett test at $5 \%$ significance. CWF - Control without flumioxazin application. *, * and $* * *$ - Significant at $\mathrm{p} \leq 0.05,0.01$ and 0.001 by $\mathrm{F}$ test, respectively. 
seeds were harvested and stored, showing no relevant variations in environmental conditions during storage. According to JUVINO et al. (2014), seeds stored in permeable packaging subjected to sudden changes in temperature and RH may undergo constant adjustments in the water content, which can cause changes in their structures.

The electrical conductivity evaluation carried out at harvest showed that an increase in herbicide doses linearly reduced the loss of electrolytes in the seed, which indicates the maintenance of the integrity of seed membranes at the highest doses. The electrical conductivity values from the dose of $25 \mathrm{~g}$ ai $\cdot \mathrm{ha}^{-1}$ were lower than the values of the comparative control (Table 2). Similarly, KAPPES et al. (2012) found that soybean seeds from the control treatment showed the highest values of electrical conductivity when subjected to increasing doses of the desiccant paraquat.

Moreover, the electrical conductivity increased after storage, with all means of the performed slices being higher than the comparative control, but with no effect of desiccant doses (Table 2). The increased electrical conductivity after the storage is expected due to the gradual loss of integrity of the seeds after the harvesting process until their death. The loss of integrity allows for a higher release of electrolytes and, consequently, higher electrical conductivity, leading to the lowest percentages of normal seedlings under this condition (Table 2).

The evaluation performed at harvest showed a higher percentage of normal seedlings at first count than after the storage period (Table 2). The stored seeds lost vigor, and the response to this variable was intensified by the effect of herbicide doses, showing a decreasing linear behavior compared to an increase in the doses, even with responses lower than the comparative control, from the dose of $25 \mathrm{~g} \cdot \mathrm{ha}^{-1}$ of flumioxazin.

The percentage of normal and abnormal seedlings obtained in the germination test and the percentage of normal seedlings after the accelerated aging test were influenced only by storage. Also, a decrease in seed germination and an increase in the number of abnormal seedlings were observed after six months (Table 1), which may indicate that the storage conditions were not efficient to preserve the physiological quality of this species.

SANTOS et al. (2005) observed similar results for common bean seeds, with reductions of 5 to $15 \%$ in the percentage of germination of four cultivars after storage for eight months under ambient conditions. However, according to these authors, the percentage of germination remained above $80 \%$ during the period in which the seeds remained stored.

The percentage of seedling emergence was not influenced by the sources of variation, with mean values varying from 92 to $88 \%$ in the two evaluation times (Table 1). These values are consistent with the behavior of this species, as it has barely undergone the genetic improvement process, being considered normal to have a lower emergence rate than plants with a high rate of genetic improvement. This characteristic may justify the lack of a significant difference in the emergency rate. These results are supported by the research carried out by DALTRO et al. (2010), who treated soybean with the desiccants paraquat and diquat for seedling emergence tests carried out in the field at the end of the storage period (eight months) and found adequate emergence compared to the control.

The emergence rate index was higher at harvest time for all doses, similarly to the control (Table 2). However, this index decreased after six months of storage, and all treatments differed from the comparative control. A decreasing linear response was also observed under this condition between doses, with a reduction of this index in the order of 0.0469 for each gram of flumioxazin applied.

Hypocotyl, primary root, and total length of seedlings, as well as root, hypocotyl, and total dry matter of seedlings showed lower values after six months of storage, even lower than the control (Table 1). However, regardless of the storage condition, the primary root and total length of seedlings were influenced by the desiccant doses and showed decreasing linear responses with a reduction of 0.1020 and $0.2449 \mathrm{~cm}$ for each gram of herbicide applied for root length and total seedling length, respectively (Fig. 1). The highest dose of flumioxazin $\left(40 \mathrm{~g}\right.$ ai $\left.\cdot \mathrm{ha}^{-1}\right)$ affected root length and total seedling length compared to the control (Table 1).

The use of flumioxazin doses in the preharvest of adzuki bean seeds did not compromise their physiological quality, but it affected the root length and total length of seedlings. However, the increased doses of flumioxazin compromised the emergence rate index and percentage of normal seedlings at first count after seed storage, resulting in less vigorous seedlings (Table 2). KAPPES et al. (2012) evaluated the effect of application times $(30,35,40$, and 45 days after flowering - DAF) and doses $\left(0,200,400\right.$, and $600 \mathrm{~g}$ ai $\left.\cdot \mathrm{ha}^{-1}\right)$ of the herbicide paraquat in common bean and found that, in general, high doses compromised the physiological seed quality and seedling growth, demonstrating the importance of the desiccation practice.

The seed sanity evaluation as a function of the tested treatments showed that the incidence of the genera Cladosporium, Fusarium, and Rhizopus was influenced by the interaction of the sources of variation desiccant doses and storage, the incidence of Aspergillus was influenced only by desiccant doses, and Penicillium was not influenced by treatments. Table 2 shows the infesting fungi found in the sanitary test.

In general, fungi that were influenced by storage had their incidence reduced after six months, which may be related to conditions under which the seeds were stored, being low temperatures and air humidity considered inadequate for the development of most pathogens found in this period. Moreover, fungi such as Fusarium are considered field pathogens that have development difficulties under storage conditions.

The sanitary evaluation carried out at harvest showed a linear decreasing response relative to the desiccant doses for the Rhizopus, Cladosporium, and Fusarium incidence. It was due to 
the better uniformity and faster maturation of plants, which probably limited the survival of these pathogens, especially Cladosporium and Fusarium, which showed lower incidences than in the comparative control (Table 2). The Rhizopus incidence was reduced after six months of storage, with a linear behavior regarding the herbicide doses used for desiccation (Table 2).

The fungus Aspergillus presented a decreasing linear behavior regarding the herbicide doses applied in the preharvest, regardless of the evaluation time, with a reduction in the incidence of $0.0705 \%$ for each gram of herbicide, with values lower than the comparative control at doses higher than $35 \mathrm{~g}$ ai ha $^{-1}$ (Table 2). The Penicillium incidence presented values close to $2.15 \%$ in both evaluations (Table 2).

The preharvest desiccation of common bean is used to anticipate harvest or when it has an uneven maturation, weed infestation, risk of rain at harvest, and favorable conditions for the incidence of pathogens that depreciate grain quality, being also important to consider the time and dose of the applied desiccant (KAPPES et al., 2012). A dose between 25 to $35 \mathrm{~g}$ ai $\mathrm{ha}^{-1}$ of flumioxazin applied as a desiccant on adzuki bean can maintain the physiological seed quality, and the preharvest desiccation reduces the infestation of seed field pathogens, such as those of the genus Fusarium. The storage of adzuki bean for six months under ambient conditions reduces the physiological seed quality, leading to a reduction in seed vigor, which is enhanced by increasing the desiccant doses.

\section{CONCLUSIONS}

Flumioxazin doses from 25 to $30 \mathrm{~g}$ ai $\cdot \mathrm{ha}^{-1}$ after harvest maintained the physiological seed quality, while lower doses increased the electrical conductivity and higher doses reduced root length and the total length of seedlings.

Storage at six months after harvest promoted a reduction in the physiological quality of adzuki bean seeds, especially when treated with the highest herbicide doses, which resulted in delaying emergence and formation of less vigorous seedlings.

Storage and increasing doses of the desiccant flumioxazin reduced the incidence of the pathogens Rhizopus, Cladosporium, and Fusarium in the seeds. Increased doses of this herbicide also reduced Aspergillus incidence.

ACKNOWLEDGEMENTS: Not applicable.

FUNDING: This study was funded by Instituto Federal de Educação, Ciência e Tecnologia Goiano. This study was financed in part by the Coordenação de Aperfeiçoamento de Pessoal de Nível Superior - Brazil - Finance Code 001.

CONFLICTS OF INTEREST: All authors declare that they have no conflict of interest.

ETHICAL APPROVAL: Not applicable.

AVAILABILITY OF DATA AND MATERIAL: The datasets generated and/or analyzed during the current study are available from the corresponding author on reasonable request.

AUTHORS' CONTRIBUTIONS: Conceptualization: Tavares, C.J.; Jakelaitis, A. Data curation: Tavares, C.J.; Sousa, M.S. Formal analysis: Tavares, C.J.; Jakelaitis, A. Methodology: Tavares, C.J.; Sousa, M.S.; Sales, J.F.; Resende, O. Writing review \& editing: Freitas, M.A.M.; Jakelaitis, A.; Resende, O.; Tavares, C.J.

\section{REFERENCES}

ALMEIDA, D.P.; RESENDE, O.; COSTA, L.M.; MENDES, U.C. Higroscopicidade das sementes de feijão adzuki. Científica, Jaboticabal, v.41, n.2, p.130-137, 2013. Available from: http:// www.cientifica.org.br/index.php/cientifica/article/view/420. Access on: 22 Mar. 2018.

ATAIDE, R.C.N.; SOUZA, C.A.; COELHO, C.M.M.; STEFEN, D.L.V.; NUNES, F.R.; TORMEN, M.E.; SANGOI, L. Effect of plant senescence inducers on landraces and commercial cultivars of common beans, World Journal of Agricultural Sciences, Faisalabad, v.11, n.3, p. 1 12-120, 2015. Available from: https://www.idosi.org/ wjas/wjas 1 1(3)15/1.pdf. Access on: 12 Mar. 2018.
BASTOS, F.J.C.; CUNHA, F.N.; RIBEIRO, N.L.; SILVA, N.F.; ROCHA, A.C.; TEIXEIRA, M.B. Resposta do feijão azuki à adubação nitrogenada sob irrigação. Revista Brasileira de Agricultura Irrigada, Fortaleza, v.7, n.6, p.349-357, 2013. https://doi.org/10.7127/ rbai.v7n600187

BRASIL. Ministério da Agricultura, Pecuária e Abastecimento. Regras para análise de sementes. Brasília: Mapa/ACS, 2009. 395p. Available from: https://www.gov.br/agricultura/pt-br/ assuntos/insumos-agropecuarios/arquivos-publicacoesinsumos/2946_regras_analise_sementes.pdf. Access on: 18 Jul. 2017. 
CARVALHO, F.J.; CARNEIRO, L.B.; VAZ, D.C.; PEIXOTO, N.; CARDOSO, A.F. Comportamento de genótipos de feijão adzuki em Ipameri-GO. Horticultura Brasileira, Brasília, v.30, n.2, p.2387-2390, 2012. Supplement. Available from: http://www.abhorticultura.com.br/ eventosx/trabalhos/ev_6/A4641_T8279_Comp.pdf. Access on: 21 Jul. 2018.

DALTRO, E.M.F.; ALBUQUERQUE, M.C.F.; FRANÇA NETO, J.B.; GUIMARÃES, S.C.; GAZZIERO, D.L.P.; HENNING, A.A. Aplicação de dessecantes em pré-colheita: efeito na qualidade fisiológica de sementes de soja. Revista Brasileira de Sementes, Londrina, v.32, n.1, p.111-122, 2010. https://doi.org/10.1590/ S0101-31222010000100013

FORTI, V.A.; CICERO, S.M.; PINTO, T.L.F. Avaliação da evolução de danos por "umidade" e redução do vigor em sementes de soja, cultivar TMG 1 13-RR, durante o armazenamento, utilizando imagens de raios $\mathrm{X}$ e testes de potencial fisiológico. Revista Brasileira de Sementes, Londrina, v.32, n.3, p.123-133, 2010. https://doi.org/10.1590/SO101-31222010000300014

FRANCO, M.H.R.; NERY, M.C.; FRANÇA, A.C.; OLIVEIRA, M.C.; FRANCO, G.N.; LEMOS, V.T. Production and physiological quality of bean seeds after application diquat. Semina: Ciências Agrárias, Londrina, v.34, n.4, p.1707-1714, 2013. https://doi. org/10.5433/1679-0359.2013v34n4p 1707

GUARESCHI, R.F.; PERIN, A.; ROCHA, A.C.; ANDRADE, D.N. Adubação com cama de frango e esterco bovino na produtividade de feijão azuki (Vigna angularis). Revista Agrarian, Dourados, v.6, n. 19, p.29-35, 2013. Available from: http://ojs.ufgd.edu.br/index. php/agrarian/article/view/1654. Access on: 13 Aug. 2018.

JUVINO, A.N.K.; RESENDE, O.; COSTA, L.M.; SALES, J.F. Vigor da cultivar BMX Potência RR de soja durante o beneficiamento e períodos de armazenamento. Revista Brasileira de Engenharia Agrícola e Ambiental, Campina Grande, v.18, n.8, p.844-850, 2014. https://doi.org/10.1590/1807-1929/agriambi. v18n08p844-850

KAPPES, C.; ARF, O.; FERREIRA, J.P.; PORTUGAL, J.R.; ALCALDE, A.M.; ARF, M.V.; VILELA, R.G. Qualidade fisiológica de sementes e crescimento de plântulas de feijoeiro, em função de aplicações de paraquat em pré-colheita. Pesquisa Agropecuária Tropical, Goiânia, v.42, n.1, p.9-18, 2012. https://doi.org/10.1590/ S1983-40632012000100002

MAGUIRE, J.D. Speed of germination - aid in selection and evaluation for seedling emergence and vigor. Crop Science, Madison, v.2, n.2, p.176-177, 1962. https://doi.org/10.2135/ cropsci $1962.0011183 \times 000200020033 x$
NEERGAARD, P. (ed.). Seed Pathology. 2nd. Ed. London: Macmillan, 1979. $1191 \mathrm{p}$.

OLIVEIRA, D.E.C.; RESENDE, O.; MENDES, U.C.; SMANIOTTO, T.A.S.; DONADON, J.R. Modelagem da contração volumétrica do feijão-adzuki durante a secagem. Científica, Jaboticabal, v.42, n.1, p.23-31, 2014. https://doi. org/10.15361/1984-5529.2014v42n1p23-31

RESENDE, O.; ALMEIDA, D.P.; COSTA, L.M.; MENDES, U.C.; SALES, J.F. Adzuki beans (Vigna angularis) seed quality under several drying conditions. Ciência e Tecnologia de Alimentos, Campinas, v.32, n.1, p.151-155, 2012. https://doi.org/10.1590/ SO101-20612012005000013

SANTOS, J.B.; FERREIRA, E.A.; SILVA, A.A.; SILVA, F.M.; SANTOS, E.A.; FERREIRA, L.R. Avaliação do carfentrazone-ethyl como dessecante em pré-colheita de sementes de feijão (Phaseolus vulgaris L.). Revista Ceres, Viçosa, v.52, n.304, p.83 1-843, 2005. Available from: http://www.ceres.ufv.br/ojs/index.php/ ceres/article/view/3091. Access on: 12 Jun. 2018.

SMANIOTTO, T.A.S.; RESENDE, O.; MARÇAL, K.A.F.; OLIVEIRA, D.E.C.; SIMON, G.A. Qualidade fisiológica das sementes de soja armazenadas em diferentes condições. Revista Brasileira de Engenharia Agrícola e Ambiental, Campina Grande, v. 18 , n.4, p.446-453, 2014. https://doi.org/10.1590/ S1415-43662014000400013

SOLTANI, N.; BLACKSHAW, R.E.; GULDEN, R.H.; GILLARD, C.L.; SHROPSHIRE, C.; SIKKEMA, P.H. Desiccation in dry edible beans with various herbicides. Canadian Journal Plant Science, Ottawa, v.93, n.5, p.871-877, 2013. https://doi.org/10.4141/ cjps2013-061

TIBURCIO, R.A.S.; FERREIRA, F.A.; FERREIRA, L.R.; MACHADO, M.S.; MACHADO, A.F.L. Controle de plantas daninhas e seletividade do flumioxazin para eucalipto. Cerne, Lavras, v.18, n.4, p.523-531, 2012. https://doi.org/10.1590/ So104-77602012000400001

TOLEDO, M.Z.; CAVARIANE, C.; FRANÇA NETO, J.B. Qualidade fisiológica de sementes de soja colhidas em duas épocas após dessecação com glyphosate. Revista Brasileira de Sementes, Londrina, v.34, n. 1, p. 134-142, 2012. https://doi.org/10.1590/ So101-31222012000100017

VIEIRA, R.D.; KRZYZANOWSKI, F.C. Teste de condutividade elétrica. In: KRZYZANOWSKI, F.C.; VIEIRA, R.D.; FRANCA NETO, J.B. (ed). Vigor de sementes: conceitos e testes. Londrina: ABRATES, 1999. chap.1, p.1-26. 